\title{
Gender Disparities in the Duration of Unemployment Spells in Slovenia
}

Polona Pašič, Alenka Kavkler, Darja Boršič *

\section{Abstract:}

The paper offers an overview of labor market characteristics in Slovenia with an emphasis on gender disparities. A survival analysis is conducted based on an extensive database obtained from the Employment Office of the Republic of Slovenia of more than 450,000 unemployment incidences between January 2004 and July 2008. Kaplan-Meier estimates of survival functions show specific disparities among unemployed women and men in Slovenia. Unemployed men are better off when re-entering the labor market as they are re-employed more quickly than women.

Keywords: gender, unemployment, labor market, survival analysis, Kaplan-Meier, Slovenia

\section{Introduction}

Human capital is one of the most important driving forces for economic competitiveness, development and growth. One half of a nation's skills, knowledge, and productivity is represented by women. In the long run, a country's economic performance depends on how effectively and to what extent female talent is well utilized. A recent analysis by Hausmann, Tyson and Zahidi (2009) shows the correlation between gender equality and level of economic development. The authors argue that empowering women leads to more efficient use of human talent. However, this finding does not apply only to the developing world. According to Daly (2007), any reduction in the gender gap would have enormous economic consequences for developed countries also. For example, closing the gap between male and female employment would boost the US GDP by $9 \%$, the Eurozone GDP by $13 \%$ and the Japanese GDP by as much as $16 \%$. Moreover, Daly (2007) argues that reducing gender inequality could contribute to solving the twin problems of population aging and pension sustainability. Establishing a friendly environment for women where it is easier for them to work and have children causes both female employment and fertility to be higher.

According to the Global Gender Gap Report (Hausmann, Tyson, and Zahidi 2009) women are as healthy and educated as men worldwide, but when considering political empowerment and economic

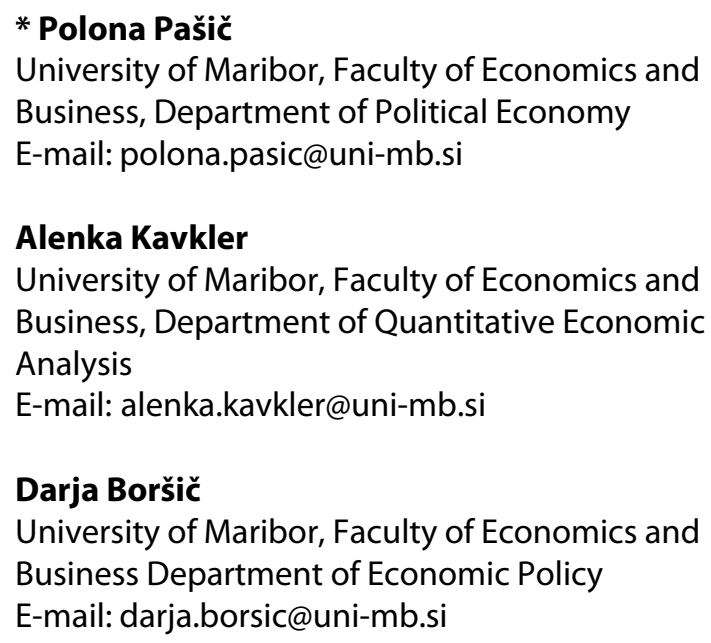


participation, women haven't advanced much and no country has actually yet reached gender equality. Slovenia ranks $52^{\text {nd }}$ among 134 countries with a gender gap index of 0.698 , where index scores range from 0 (inequality) to 1 (equality). Of the four components of the index, the educational attainment subindex is the highest (0.998) followed by health and survival (0.973), and economic participation and opportunity (0.721). The lowest score (0.100) was for the political empowerment of women. According to the Human Development Report (United Nations 2009) Slovenia belongs to a group of countries with very high human development. In terms of gender disparities in Slovenia, 34\% of legislators, senior officials and managers are female, and $56 \%$ of professional and technical workers are female. Women held $18 \%$ of ministerial positions in January 2008 and $10 \%$ of seats in the parliament in February 2009.

In the last couple of decades, different survival analysis and duration techniques have gained popularity in the social sciences to model the length of unemployment spells and strike duration. Moffitt (1999) applied the usual econometric techniques in labor economics, including proportional hazard methods and duration models. Examples of duration model applications in labor markets can be found in Green and Riddell (1995), D'Agostino and Mealli (2000), and Arranz and Romero (2003). They explain the effects of the different determinants of unemployment duration for Canada, nine EU15 members and Spain. Factors of unemployment duration in Ukraine are discussed in Kupets (2006), using the Cox proportional hazard model with two competing risks. The author concludes that age, marital status, income during unemployment and local demand constraints significantly affect the duration of unemployment.

Vodopivec (1995, 2004), Domadenik and Pastore (2006), Orazem, Vodopivec, and Wu (2005) and Kavkler and Boršič $(2006,2007)$ have all analyzed Slovenian unemployment. Vodopivec (1995) used a duration model to study the effects of unemployment insurance on unemployment duration. Domadenik and Pastore (2006) tested the impact of education and training systems on the participation of young people in the labor markets of Slovenia and Poland. The above papers are devoted to the aggregate labor market in Slovenia. Indeed, analytical papers dealing with gender issues of unemployment in Slovenia are rare. Thus, this paper attempts to estimate the effect of gender disparities on the duration of unemployment in Slovenia by using duration data techniques, namely the Kaplan-Meier estimator.

Aware of the importance of female participation in economic activities, the EU strives for average female employment of at least $60 \%$ (the Lisbon Strategy). Slovenia has already reached the Lisbon goal, but the overall employment rate still needs to be higher. Thus, maintaining and ameliorating the high employment of women is of crucial importance. The analyzed topic is of special importance to Slovenia, since employment policy has to identify the main factors that influence the duration of unemployment and establish precise mechanisms to target specific unemployed groups more effectively. By clearly identifying gender disparities in the duration of unemployment, this paper contributes to the implementation of an optimal employment policy for Slovenia.

The paper is structured as follows. The introduction is followed by an overview of the characteristics of the total unemployment rate in Slovenia. Then, gender issues in the unemployment rate are discussed and compared to the European average. Next, a brief presentation of duration models and survival analysis is given, followed by a description and preliminary analysis of the dataset with the results of Kaplan-Meier estimates. The paper concludes with a short summary of the main findings.

\section{Characteristics of the Unemployment Rate in Slovenia}

Table 1 presents the registered and ILO unemployment rates in Slovenia for the period between 2000 and 2009. The registered rate of unemployment decreased from 2000 to 2008, and then increased in 2009. In 2000 , the average rate of unemployment was $12.2 \%$ (the average number of unemployed was 106,601), and in $2008,6.7 \%$ (the average number of unemployed then was $63,216)$. The decrease in the level of unemployment was mainly due to the economy performing well in Slovenia. In 2000, the Slovenian GDP was 21,435 mio EUR (in current prices) and then increased to 37,135 mio EUR in 2008. In 2009, the Slovenian GDP decreased to 34,894 mio EUR, and the average rate of unemployment increased to $9.1 \%$, or by 2.4 percentage points when compared to 2008.

The registered unemployment rate in Slovenia was higher than the ILO unemployment rate for the period 2000 - 2009. The main reasons for the differences were in the high unemployment benefits, the high level of 


\begin{tabular}{lcccccccccc}
\hline Unemployment rate & $\mathbf{2 0 0 0}$ & $\mathbf{2 0 0 1}$ & $\mathbf{2 0 0 2}$ & $\mathbf{2 0 0 3}$ & $\mathbf{2 0 0 4}$ & $\mathbf{2 0 0 5}$ & $\mathbf{2 0 0 6}$ & $\mathbf{2 0 0 7}$ & $\mathbf{2 0 0 8}$ & $\mathbf{2 0 0 9}$ \\
\hline Registered & 12.2 & 11.6 & 11.6 & 11.2 & 10.6 & 10.2 & 9.4 & 7.7 & 6.7 & 9.1 \\
ILO & 6.7 & 6.2 & 6.3 & 6.7 & 6.3 & 6.5 & 6 & 4.9 & 4.4 & 6.0 \\
\hline Difference (\% points) & 5.5 & 5.4 & 5.3 & 4.5 & 4.3 & 3.7 & 3.4 & 2.8 & 2.3 & 3.1 \\
\hline
\end{tabular}

Source of data: Employment Office of the Republic of Slovenia (registered) and Eurostat (ILO).

Table 1: Registered and ILO unemployment rates in Slovenia

\begin{tabular}{lrrrrrrrrrrr}
\hline Duration & $\mathbf{2 0 0 0}$ & $\mathbf{2 0 0 1}$ & $\mathbf{2 0 0 2}$ & $\mathbf{2 0 0 3}$ & $\mathbf{2 0 0 4}$ & $\mathbf{2 0 0 5}$ & $\mathbf{2 0 0 6}$ & $\mathbf{2 0 0 7}$ & $\mathbf{2 0 0 8}$ & $\mathbf{2 0 0 9}$ \\
\hline Up to 3 months & 17.9 & 20.2 & 20.2 & 23.6 & 25.5 & 22.7 & 22.4 & 21.7 & 27.6 & 27.3 \\
From 3 to 6 months & 10.0 & 13.2 & 13.0 & 14.0 & 14.3 & 13.9 & 11.3 & 12.6 & 12.8 & 14.0 \\
From 6 to 9 months & 5.5 & 6.2 & 7.0 & 8.4 & 8.2 & 8.8 & 8.1 & 7.8 & 7.1 & 12.0 \\
From 9 to 12 months & 5.2 & 5.8 & 7.5 & 8.0 & 7.5 & 8.3 & 7.5 & 7.2 & 6.1 & 11.1 \\
From 1 to 2 years & 15.3 & 14.2 & 18.5 & 19.1 & 19.4 & 18.3 & 20.4 & 18.2 & 16.4 & 15.3 \\
From 2 to I 3 years & 12.1 & 9.0 & 8.1 & 9.7 & 9.1 & 9.5 & 9.7 & 10.3 & 8.4 & 6.2 \\
From 3 to 5 years & 16.4 & 13.5 & 10.2 & 7.3 & 7.7 & 8.8 & 9.7 & 10.1 & 9.4 & 6.0 \\
From 5 to 8 years & 10.5 & 9.3 & 7.5 & 4.4 & 3.6 & 4.5 & 5.3 & 6.3 & 6.5 & 4.3 \\
More than 8 years & 7.2 & 8.6 & 7.9 & 5.4 & 4.7 & 5.2 & 5.5 & 5.9 & 5.7 & 3.8 \\
\hline Total & 100 & 100 & 100 & 100 & 100 & 100 & 100 & 100 & 100 & 100 \\
\hline Source of data: Employ
\end{tabular}

Source of data: Employment Office of the Republic of Slovenia.

Table 2: Duration of registered unemployment in Slovenia as \% of total number of unemployed

informal work and the high level of long-term unemployed who were not actively seeking a job (Kajzer 2005). For the period $2000-2009$, the difference between the rates decreased from 5.5 percentage points in 2000 to 3.1 percentage points in 2009 , with the lowest difference of 2.3 percentage points achieved in 2008. In this paper, a comparison of Slovenia to the European Union and the Euro area is presented based on the ILO rates, while the analysis is based on registered unemployment data gathered by the Employment Office of the Republic of Slovenia.

A decrease in the difference between the rates relates to the changes that occurred in long-term unemployment. In 2000, unemployment of more than 1 year amounted to $61.5 \%$ of all unemployed workers, whereas in 2008 and 2009 the same type of unemployment amounted to $46.4 \%$ and $35.6 \%$ of all unemployed workers, respectively (Table 2 ).

In 2009, the unemployment rate in Slovenia (6.0\%) was below the unemployment rate of EU27 (8.9\%), and also below the Euro area unemployment rate (9.4\%). According to the Labor Force Survey (Figure 1), the unemployment rate in Slovenia for the observed period was 2.4 and 2.3 percentage points lower than the European Union average and the Euro area average, respectively.

The long-term unemployment rates for Slovenia were also below the average of EU27 and the Euro area (Figure 2). The long-term unemployment rate for Slovenia in 2009 amounted to $1.8 \%$, whereas the long-term unemployment rates for EU27 and the Euro area amounted to $3.0 \%$ and $3.3 \%$, respectively. For the period 2000 - 2009, the long-term unemployment rate for Slovenia was on average 0.6 percentage points below the average of both the EU27 and the Euro area.

Table 2 presents statistics for the duration of registered unemployment in Slovenia in terms of the percentage of the total number of the unemployed. For the period $2000-2009$ the highest share is represented by unemployment spells of up to 3 months, mainly due to the fact that in the first three months of unemployment the unemployed receive a share of their previous wages as a financial compensation if they had been employed for at least a year. Unemployment of more than 1 year 


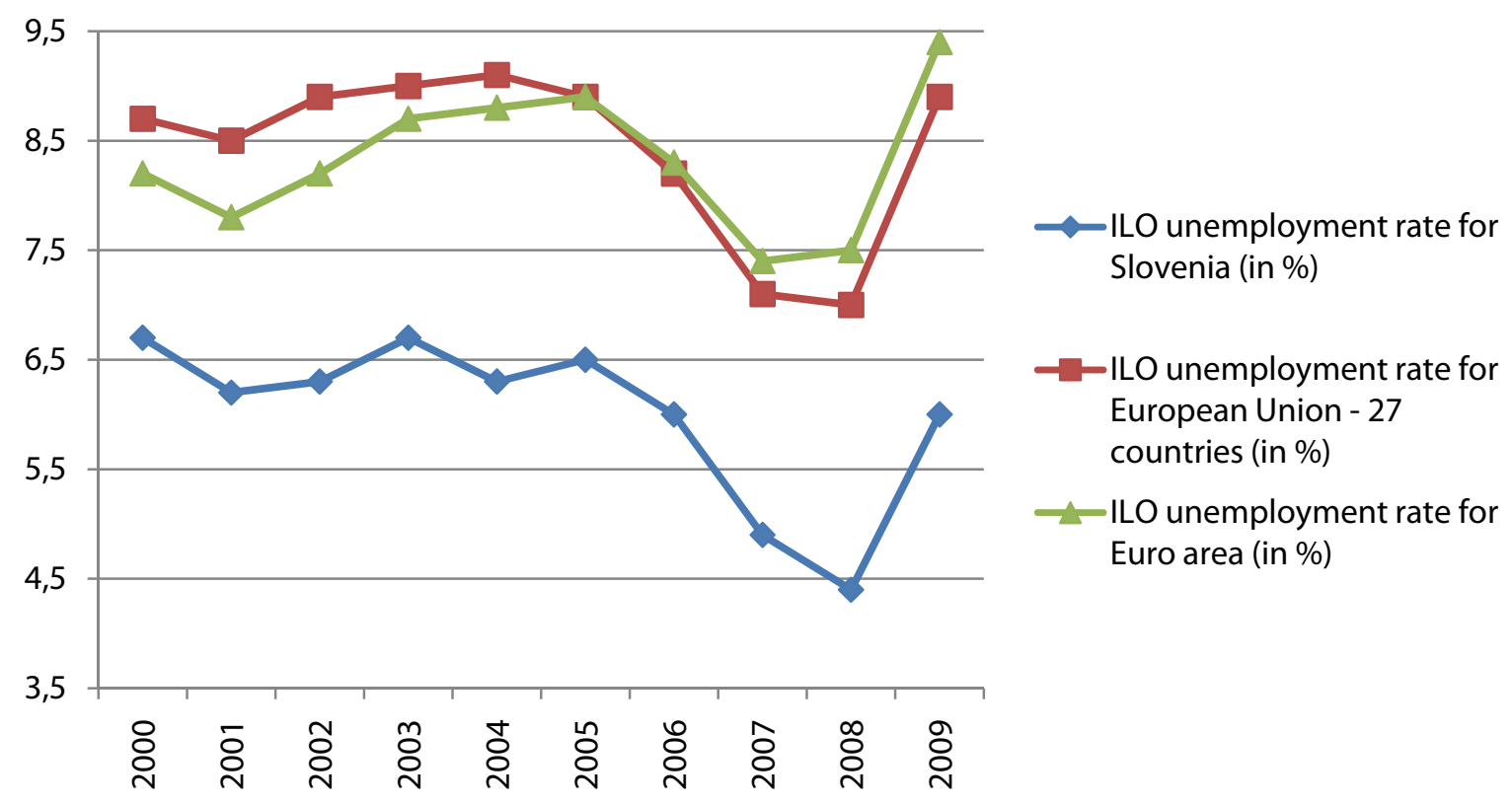

Source of data: Eurostat.

Figure 1: ILO unemployment rates for Slovenia, European Union (27) and Euro area.

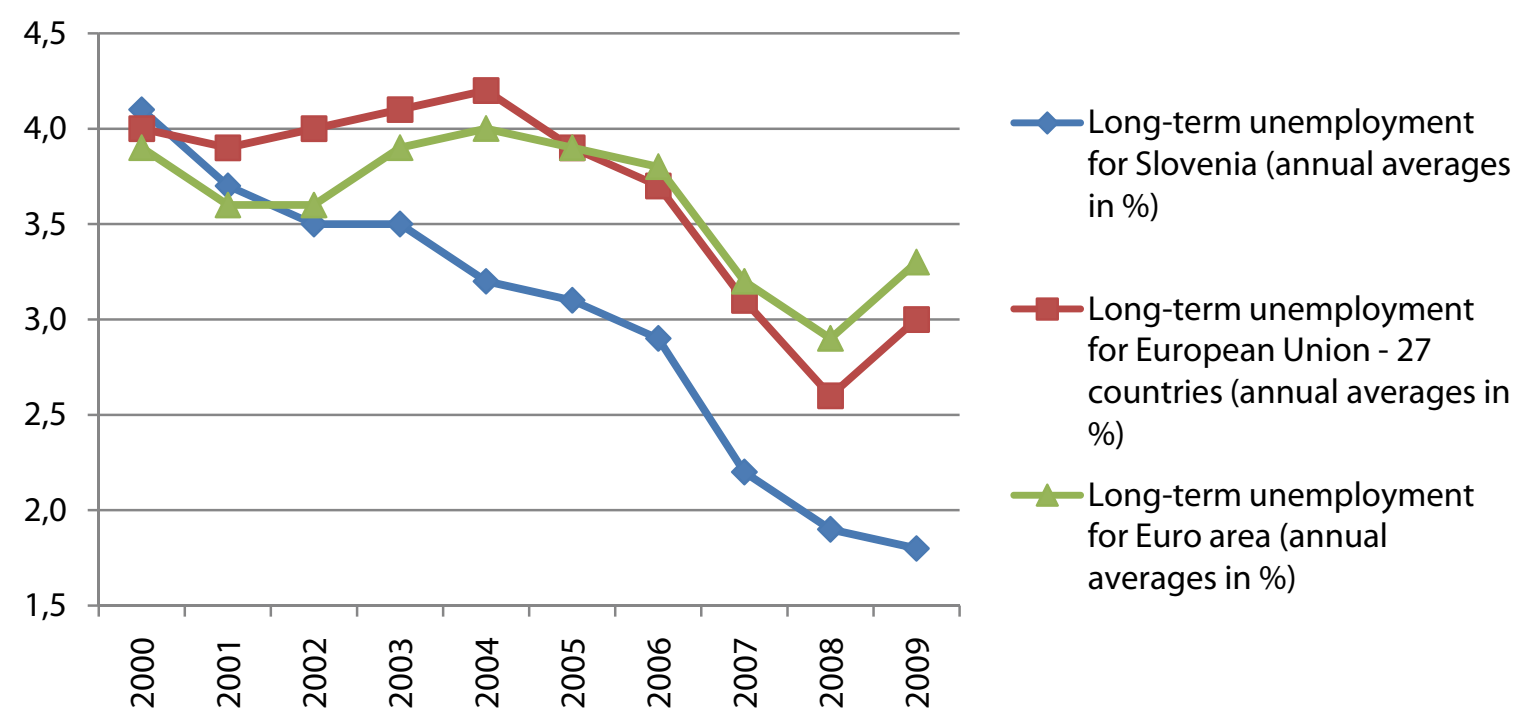

Source of data: Eurostat.

Note: Long-term unemployment for the EU27 for the year 2005 is an estimate only, since official data is not available.

Figure 2: Long - term unemployment rates for Slovenia, the European Union (27) and the Euro area.

decreased from $61.5 \%$ in 2000 to $35.6 \%$ in 2009 . The largest decrease (10.4 percentage points) was identified for unemployment that lasted from 3 to 5 years.

\subsection{Gender disparities in the Slovenian labor market}

In 2008, the population of Slovenia was 2,032,362, of which $50.5 \%$ were women and $49.5 \%$ were men (SORS 2009a). According to the Statistical Office of the Republic of Slovenia (SORS 2009b) there were 942,473 people in the workforce in 2008 , of which $44 \%$ were women and $56 \%$ were men.

In 2008, the highest percentage of employed persons were in manufacturing (26.1\%) and in wholesale, retail trade and repair of motor vehicles and motorcycles (12.0\%) (SORS 2009a). In terms of gender, $31.1 \%$ of men 


\begin{tabular}{ccccccccc}
\hline Year & $\%$ & Year & $\%$ & Year & $\%$ & Year & \% \\
\hline 1990 & 47.2 & $\mathbf{1 9 9 5}$ & 47.2 & $\mathbf{2 0 0 0}$ & 50.3 & $\mathbf{2 0 0 5}$ & $\mathbf{2 0 0 6}$ & 54.7 \\
1991 & 44.2 & $\mathbf{1 9 9 6}$ & 48.2 & $\mathbf{2 0 0 1}$ & 50.8 & $\mathbf{2 0 0 0}$ \\
1992 & 43.9 & $\mathbf{1 9 9 7}$ & 48.9 & $\mathbf{2 0 0 2}$ & 51.6 & $\mathbf{2 0 0 7}$ & 53.7 \\
1993 & 438 & $\mathbf{1 9 9 8}$ & 50.0 & $\mathbf{2 0 0 3}$ & 52.4 & $\mathbf{2 0 0 8}$ & 50.8 \\
1994 & 45.7 & $\mathbf{1 9 9 9}$ & 50.6 & $\mathbf{2 0 0 4}$ & 52.7 & $\mathbf{2 0 0 9}$ & 48.1 \\
\hline
\end{tabular}

Source of data: Employment Office of the Republic of Slovenia and Statistical Yearbook 2009.

Table 3: Share of women in total number of registered unemployed in Slovenia, end of year

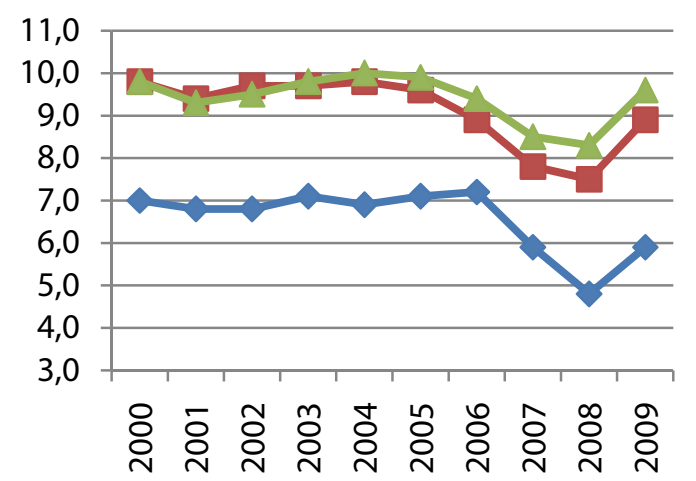

$\neg$ ILO unemployment rate for Slovenia (in \%) - women

-ILO unemployment rate for European Union - 27 countries (in \%) - women

-ILO unemployment rate for Euro area (in\%) - women

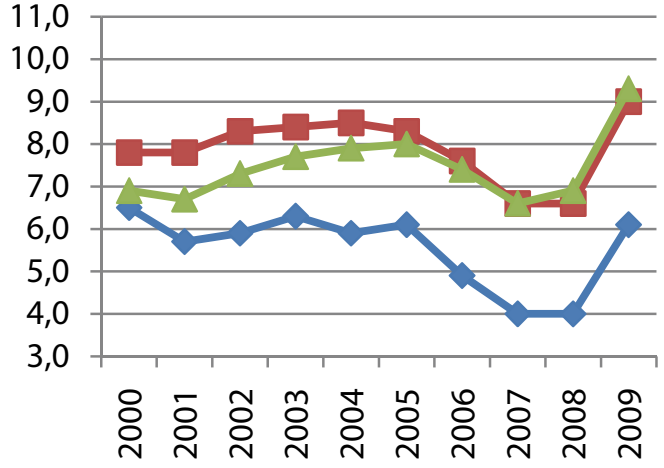

$\_$ILO unemployment rate for Slovenia (in $\%)$ - men

-ILO unemployment rate for European Union - 27 countries (in \%) - men

- ILO unemployment rate for Euro area (in \%) - men

Source of data: Eurostat.

Figure 3: ILO unemployment rates for Slovenia, European Union (27) and the Euro area, for women and men.

were employed in manufacturing and $11 \%$ in construction, whereas for women $20.2 \%$ were employed in manufacturing, $14.4 \%$ in wholesale, retail trade and repair of motor vehicles and motorcycles and $13.0 \%$ in education.

According to the Employment Office of the Republic of Slovenia, there were 66,239 registered unemployed persons at the end of 2008 , with $50.8 \%$ women and $49.2 \%$ men (see Table 3). Due to the economic crisis there was an increase in unemployment to 96,672 registered unemployed persons by the end of 2009. This was also the first year after 1998 with fewer women $(48.1 \%)$ than men $(51.9 \%)$ in the total number of registered unemployed in Slovenia, mostly due to the characteristics of the sectors hurt the most in the current crisis, and which also affected men more than women in those sectors (construction). A similar trend, the lower level of unemployed women compared to men, was also present from 1990 to 1998, due to the economic transformation, which mostly affected heavy industry where more men were laid off than women. After 1998 the textile industry crisis caused more female unemployment.

Regarding unemployed men in Slovenia in 2008, $32.2 \%$ had technical or general upper secondary education, $30.8 \%$ had short-term vocational and vocational upper secondary education, and $19.2 \%$ had only elementary school education. Out of all the unemployed women in Slovenia in $2008,36.9 \%$ had a technical or general upper secondary education, $22.1 \%$ had tertiary education and $21.6 \%$ had short-term vocational or vocational upper secondary education. It is interesting to note that one fifth of unemployed women (22.1\%) had tertiary education, compared to only $14.5 \%$ of unemployed men who had the same level of 
education. Figure 3 presents the ILO unemployment rates for Slovenia in comparison to rates in the European Union (27 countries) and the Euro area for women and men. Unemployment rates for women in Slovenia, EU27, and in the Euro area were higher than the unemployment rates for men in the period $2000-2008$, although that situation slightly changed in 2009. In 2009, the ILO unemployment rate favored women in Slovenia and the EU27 with a difference of 0.2 percentage points for Slovenia and 0.1 percentage points for EU27 in comparison to men. In the Euro area, however, women still experienced a higher ILO unemployment rate $(9.6 \%)$ compared to men $(9.3 \%)$ in 2009.

Similar to the ILO unemployment rates, the long-term unemployment rates for Slovenian women and men differed the most in 2006 by 1.0 percentage point and the least in 2000 and 2002 by 0.1 percentage points. Greater long-term unemployment differences between women and men were recorded in EU27 and in the Euro area, on average 0.7 percentage points and 1.1 percentage points, respectively.

As there are differences in unemployment rates and duration of unemployment by gender, there are also differences in salaries by gender. In 2008, the average gross monthly salary in Slovenia amounted to 1,431 EUR. Women earned $92.4 \%$ of the average gross monthly income of men. Among the economic sectors, the greatest difference in salaries appeared in the financial and insurance services, and health and social work services where the difference in favour of men amounted to $33.8 \%$ and $30.6 \%$, respectively. In 2008 , women had higher salaries in comparison to men in the following employment areas: water supply, sewerage, waste management and remediation services, construction, and transportation and storage (SORS 2010).

According to Eurostat, the average gender wage gap in Slovenia is among the smallest in the EU. Kajzer (2006) argues that this is due to a prolonged wage equality mechanism from the previous social economic structure and the current legal framework, the relatively low level of part-time and temporary employment compared to other European countries, a compulsory proportional wage supplement for the employment period for both women and men, and a high rate of female employment in the public sector, where salaries are higher when compared to the private sector.

\section{Survival Analysis and Duration Models}

Survival analysis and duration models originate in biostatistics, where the survival time is the time until death or until relapse of an illness. During the recent years these techniques have also gained popularity in the social sciences to model length of unemployment spells and strike duration. One of the unavoidable problems encountered when analyzing duration data is so-called censoring. Since the event under observation (i.e. death or the end of an unemployment spell) often does not occur until the end of the study, it is only possible to estimate the lower bound of the survival time. This kind of censoring is called right censoring.

A comprehensive overview of the methods and models used in survival analysis is given by Therneau and Grambsch (2000) and also by Klein and Moeschberger (1998).

\subsection{Basic notions}

Let the random variable $T$ denote survival time. The distribution function of $\mathrm{T}$ is defined by the equation

$$
F(t)=P(T<t)
$$

and measures the probability of survival up to time $t$. Since $T$ is a continuous random variable, its density function can be computed as the first derivative of the distribution function $f(t)=F^{\prime}(t)$. The survival function $\mathrm{S}(\mathrm{t})$ denotes the probability to survive until time $\mathrm{t}$ or longer and is given by

$$
S(t)=P(T \geq t)=1-F(t) .
$$

The limit

$$
\lambda(t)=\lim _{\delta \rightarrow 0} \frac{P(t \leq T<t+\delta \mid T \geq t)}{\delta}
$$

(3)

represents the risk or proneness to death at time t. The function $\lambda(t)$ is usually called the hazard function or the failure rate and measures the instantaneous death rate given survival until time $t$. Because any of the functions $F(t), S(t), f(t)$, and $\lambda(t)$ may be expressed with the help of any of the remaining three functions, one can decide to model any one of them and estimate the others from the derived equations.

The parametric survival models are often used in practice because of their simplicity. It has to be emphasized, however, that they impose a complex 


\begin{tabular}{|c|c|c|c|c|}
\hline & $N$ & Mean & $\begin{array}{l}\text { Standard } \\
\text { deviation }\end{array}$ & $\begin{array}{l}\text { 95\% confidence interval for } \\
\text { mean }\end{array}$ \\
\hline Total & 389.904 & 378 & 623 & $(376,380)$ \\
\hline \multicolumn{5}{|c|}{ Gender } \\
\hline Men & 188.887 & 354 & 611 & $(351,357)$ \\
\hline Women & 201.026 & 400 & 633 & $(397,403)$ \\
\hline
\end{tabular}

Table 4: Descriptive statistics for length of unemployment spells (in days)

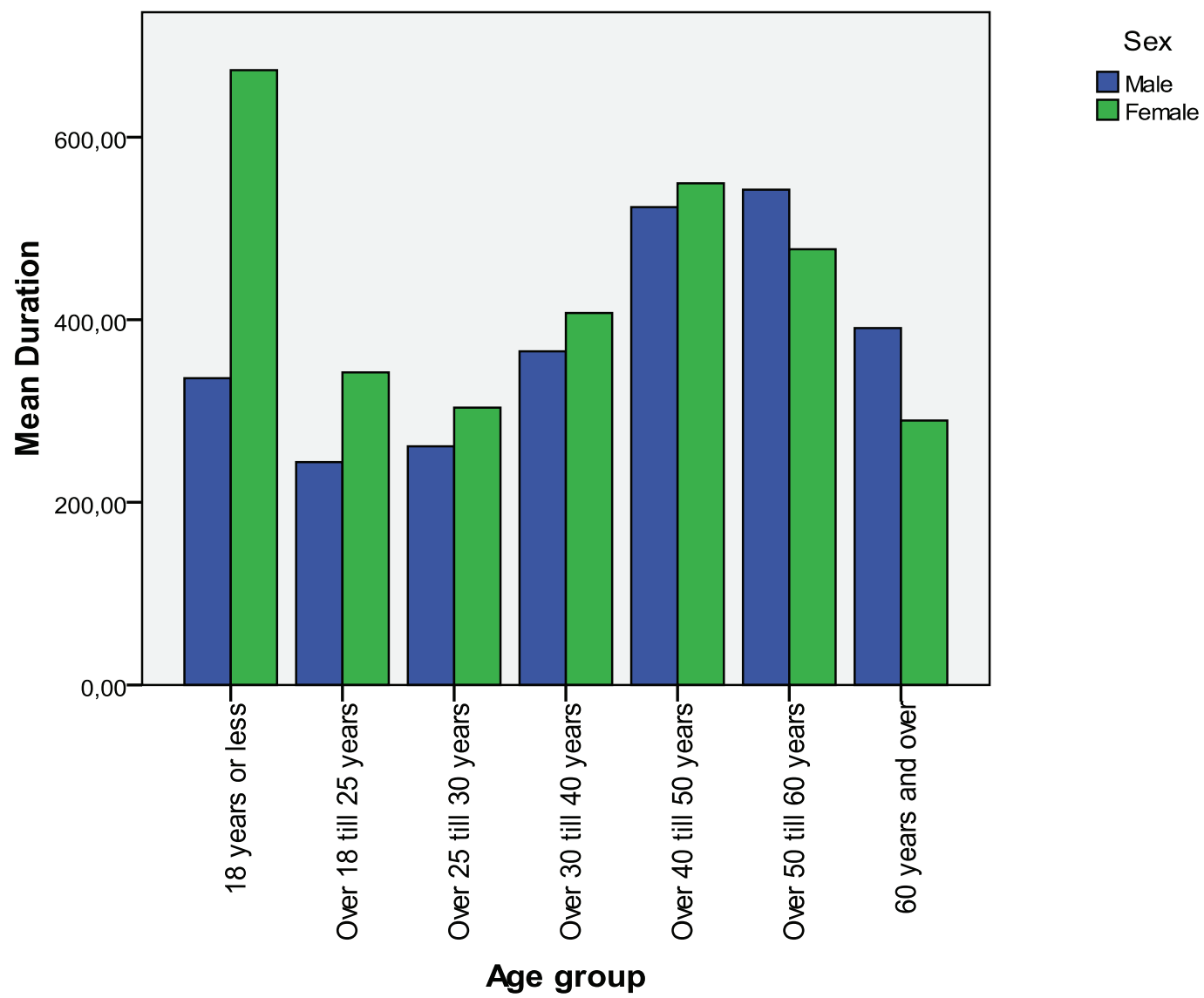

Figure 4: Gender disparities according to age

structure on the data, which can lead to distortions in the estimated hazard rates. Better models can be obtained by using nonparametric methods that impose very few restrictions.

\subsection{Kaplan - Meier estimator}

The derivation of the Kaplan - Meier estimator for the survival curve can be found in Greene (2003). This estimator of the survival function is also called the product limit estimator for reasons that shall be clear later on. Given $\mathrm{n}$ individuals with $\mathrm{p}$ distinct survival times $t_{1}<t_{2}<\ldots<t_{p}$ and $d_{i}$ deaths at $t_{i}$, assume at first that no censoring occurs. For the time $t$ from the interval $\left[t_{s}, t_{s+1}\right)$ the survival function can be estimated as follows:

$$
\hat{S}(t)=1-\hat{F}(t)=\frac{n-\sum_{j=1}^{s} d_{j}}{n}, \quad t_{s} \leq t<t_{s+1} .
$$

If the numerator and the denominator of the previous expression are successively multiplied by factors of the form $n-d_{1}-d_{2}-\ldots-d_{i}, \quad i=1,2, \ldots, s-1$, one obtains

$$
\hat{S}(t)=\frac{n-d_{1}}{n} \cdot \frac{n-d_{1}-d_{2}}{n-d_{1}} \cdot \ldots \cdot \frac{n-d_{1}-d_{2}-\ldots-d_{s}}{n-d_{1}-\ldots-d_{s-1}}
$$




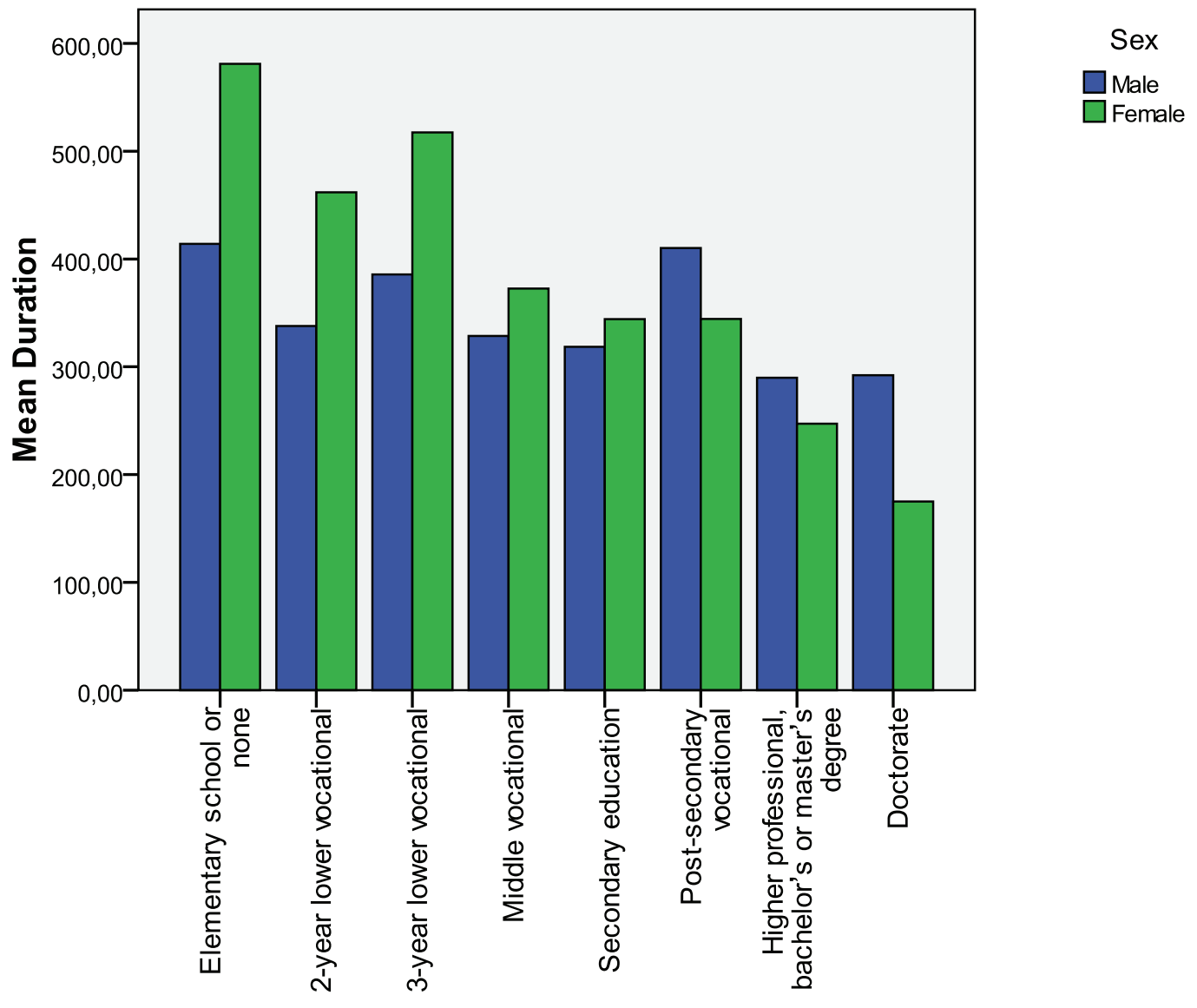

\section{Education}

Figure 5: Gender disparities according to education

Let $r_{i}, i=2, \ldots, p$, denote the number of individuals whose observed survival time is at least $t_{i-1}$ and let $r_{1}=n$. In other words, the number at risk $r_{i}$ takes into account all individuals alive during the time interval $\left[t_{i-1}, t_{i}\right)$. Under the assumption of no censoring the equation $r_{i+1}=r_{i}-d_{i}$ holds, whereas $r_{i+1}=r_{i}-d_{i}-c_{i}$ if censorings do occur, with $c_{i}$ equal the number of censored observations in the interval $\left[t_{i-1}, t_{i}\right)$. The final version of the Kaplan - Meier estimator can thus be written as

$$
\hat{S}(t)=\left(1-\frac{d_{1}}{r_{1}}\right) \cdot \ldots \cdot\left(1-\frac{d_{s}}{r_{s}}\right)=\prod_{j=1}^{s}\left(1-\frac{d_{j}}{r_{j}}\right), \quad t_{s} \leq t<t_{s+1} .
$$

(6).

\section{Database and results}

The database for our analysis was obtained from the Employment Office of the Republic of Slovenia and consists of registered unemployment spells completed between January 1, 2004 and July 4, 2008. For each unemployment spell, we obtain information about start and end date, gender, age, education level and region. Since the Employment Office of the Republic of Slovenia is not allowed to disclose personal data about the unemployed, a personal identifying number was added to enable identification of repeated unemployment spells. Our database includes 451,320 unemployment spells, out of which $61,416(13.6 \%)$ are censored. The maximum length for a completed unemployment spell was 10,637 days.

Empirical analysis was conducted using SPSS and R. Table 4 presents the mean, standard deviation and the 95\% confidence intervals for the mean for gender. The 389,904 unemployment spells completed between 


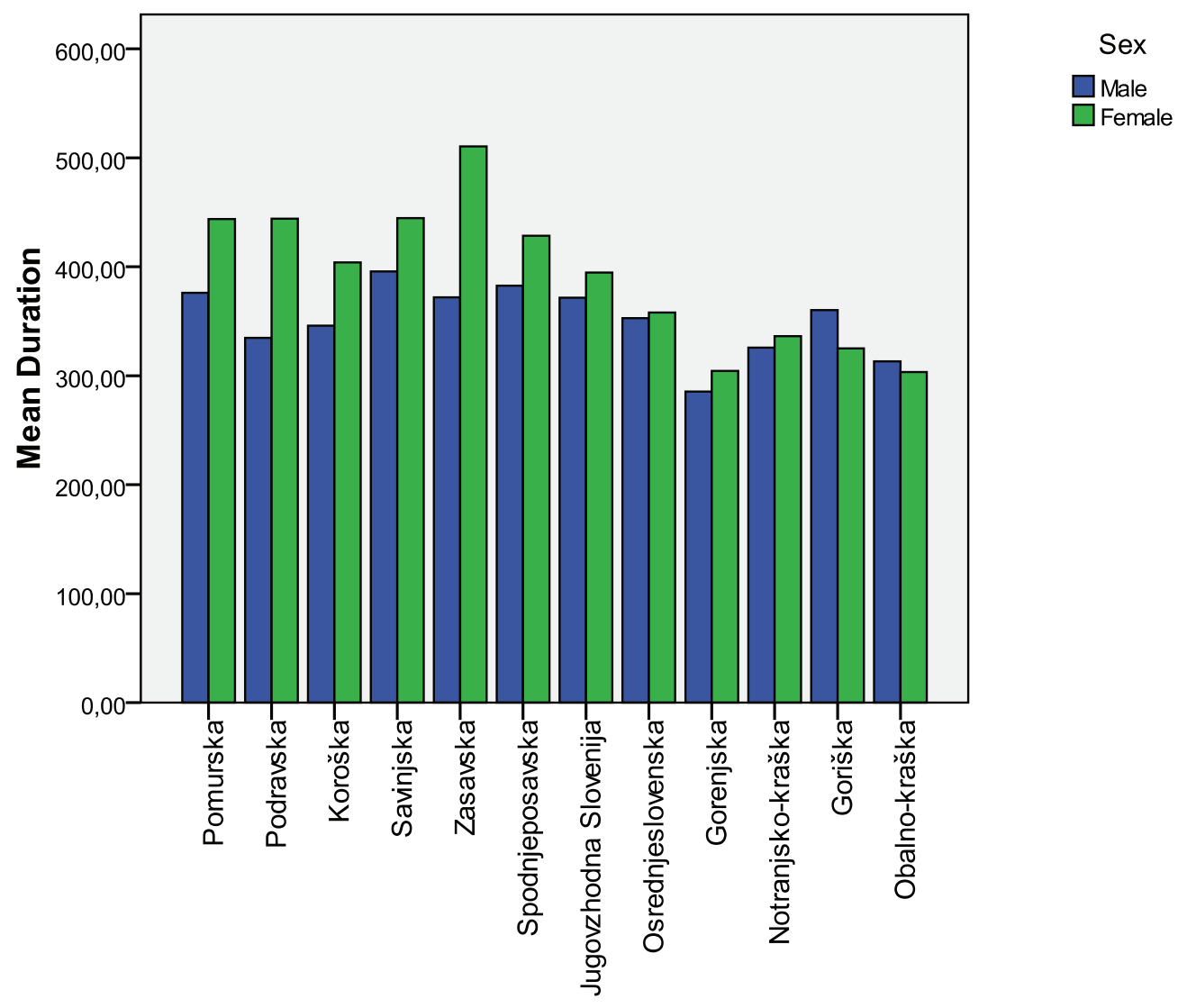

Region

Figure 6: Gender disparities according to region

January 1, 2004 and July 4, 2008 were included in the analysis. In the observed period, the average length of unemployment was 378 days. The unemployment spells were on average 46 days (13\%) longer for women than for men.

Women aged 18 years or less were unemployed for the longest period with a mean length of unemployment spells of 673 days (Figure 4). Men, on the other hand, exhibited the longest duration of unemployment spells in the age group 50 to 60 years (542 days). In total, the longest duration of unemployment spells was among those between 40 and 50 years with the mean length of unemployment spells being 537 days. Those between 25 and 30 years were on average unemployed only for 286 days.

The longest mean length of unemployment was for women with elementary school or no education (581 days, Figure 5). Women with a doctorate took on average the least time (175 days) to get a new job. Men with the longest period of unemployment were those with elementary school or no education, who needed on average 414 days to become employed again. With increased education level, however, the situation changes in favor of women. For men with post-secondary vocational or higher education, the mean duration of unemployment was 331 days and for women 255 days. On the other hand, duration of unemployment for men with lower education (i.e. elementary school or none to secondary education) was shorter compared to unemployed women, with an average mean length of 357 and 455 days, respectively. In total, the longest mean length of unemployment spells was held by the unemployed with elementary school or no education (487 days). With an increased level of education, the mean length of unemployment spells decreased to 230 days (for those unemployed with a doctorate).

Figure 6 depicts the regional disparities for duration of unemployment spells for women and for men. In all the regions except Goriška and Obalno-kraška, it takes more time for women to be re-employed than it takes for men. 
In Goriška and Obalno-kraška the mean duration of unemployment spells for women was 35 days and 10 days, respectively, lower than for men. For women in the Zasavska region, unemployment took the longest, on average (510 days). Men with the longest mean length of unemployment spells were in the Savinjska region (396 days). In total, the longest mean length of unemployment spells appeared in the Zasavska region (444 days) and the shortest in the Gorenjska region (296 days).

\subsection{Results of the Kaplan-Meier analysis}

Recall that the survival function $S(t)$ denotes the probability for an unemployment spell to last until time $t$ or longer. Figure 7 presents survival function estimates for women and men. The differences for gender are clearly visible. The estimate for unemployed women decreases to 0 with a slower rate, indicating that unemployed men have a better position in the labor market. Figure 7 shows almost coinciding survival functions for women and men after 4 years of unemployment spells, implying that the differences among gender are more pronounced for unemployment spells that last less than 4 years.

To test the null hypothesis that the survival functions are the same for two or more levels of a given factor, the log rank test with the $\chi^{2}$ - distribution under the null can be used. When performed for our data using the factor gender, the highly significant $\mathrm{p}$ - value (lower than $10^{-16}$ ) confirms the results derived graphically from the Kaplan - Meier estimates of the survival function.

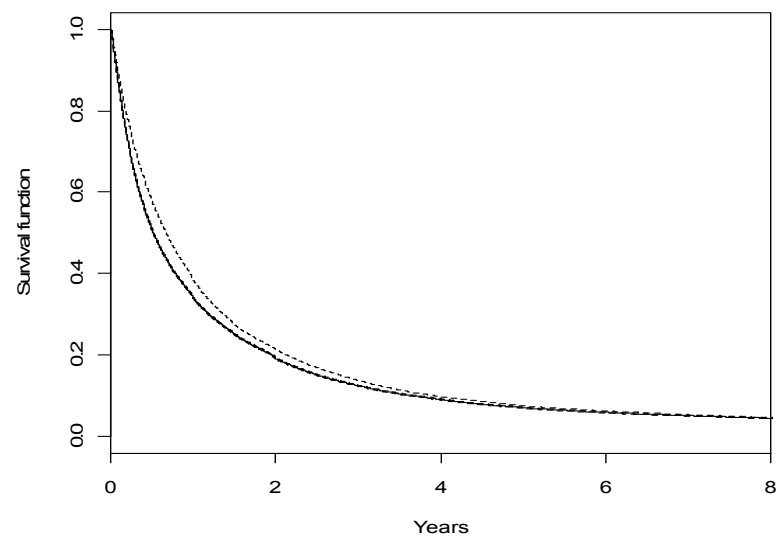

Figure 7: Kaplan-Meier estimates of survival functions by gender (dotted line indicates women)
The results are in line with studies of other countries. Examples of the research done on gender disparities for the duration of unemployment spells can be found in Danacica (2009) and Tansel and Tasci (2004). Both authors came to the same conclusion: the duration of unemployment for women is higher than the duration of unemployment for men. The study by Danacica (2009) for a Romanian county shows that the employment probability for men registered as unemployed is $1.6 \%$ higher than the probability for women with the same status. Tansel and Tasci (2004) also found that women experience higher unemployment durations than men, meaning that the probability for ending unemployment is substantially lower for women than for men.

The results of the analysis for Finland (Ollikainen 2006) indicate that the labor market position of women differs from men. Female labor market position is inferior to men's and is more responsive to family-related background characteristics. While having a family turned out to be an insignificant or a positive factor for men, it was mainly a negative factor for women, since it motivated women to stay at home, either as nonparticipants or as unemployed. Moreover, the study reveals that unemployment history is particularly scarring for men as they are penalized more than women. Women in Finland are expected to have a lower attachment to the labor market. There was a significant correlation between education and the probability of employment for both men and women, but the influence of education on women was stronger. Women with a high level of education had a better probability of employment than men.

Orazem, Werbel and McElroy (2003) showed that women had lower starting-pay-expectations: the differences were present even for men and women with the same major, job-market information, and job-search strategies. Lower pay expectations also led to lower pay outcomes for women. Women who engaged more intensively in career planning had pay expectations and starting pays that were more in line with those of men.

The research conducted by Lentz and Tranaes (2005) on Danish micro data showed that the job-finding effort of married men and women was affected by the income of their spouses, but in opposite directions. The more the man earned and the wealthier the woman, the longer it took for her to find a job. On the other hand, the results for men showed that the more the wife earned, the faster the husband found a job. 
Löfmark (2008) found that being a married man simplified job findings. As the author suggests, this may be due to discrimination, a pattern of male breadwinners, or difficulties women have in combining housework and efficient job seeking.

One of the ways to lower unemployment is also selfemployment. Entrepreneurship is an important source of innovation and overall economic growth and development. In Slovenia, it is rarer for women to start their own company due to fewer business opportunities, but when they do, they have as high an ambition for growth as their male counterparts (Tominc and Rebernik 2010).

\section{Conclusion}

Our analysis of gender disparities in the duration of unemployment spells in Slovenia reveals that there were more unemployed women than men in the period from 1999 to 2008. In 2009, that trend slightly changed, with a higher percentage of unemployed men $(51.9 \%)$ than women (48.1\%). The same trend, favoring women, was present also in the period from 1990 to 1998.

Survival analysis of the duration of unemployed spells presented in this paper was based on a dataset with more than 450,000 unemployment spells for individuals between January 2004 and July 2008. The analysis yielded the following results. The unemployment spells lasted on average 46 days (13\%) longer for women than for men. Regarding the gender disparities based on age, women were unemployed longer than men in all age groups until 50 years old. After 50 the trend changes, and the duration of unemployment for men becomes longer than for women. Regarding gender disparities according to education, our analysis showed that unemployed women with post-secondary vocational or higher education have a better position in the labor market than men. Women with secondary education or lower, on the other hand, need more time to find a job than men. Gender disparities according to region showed that unemployed men find a job sooner than women in all regions, except in Goriška and Obalno-kraška. In the Goriška region unemployed men had to wait on average 35 days longer than women and in the Obalno-kraška region 10 days longer than women to find a job.

The empirical analysis offered here suggested that gender disparities in the duration of unemployment spells in Slovenia are significant. There are various reasons for gender disparities, and these can be found in the roles women play in families (the role of women in families is still perceived as quite stereotypical - women take care of family, and men earn money), unwillingness to move, less access to social networks and wage discrimination (on average women are still paid less than men).

Women still have difficulties getting employed even when they are highly educated. It is even more difficult for them to achieve higher positions. However, the situation has been changing over the last few years. The greater empowerment of women has led to women running big companies and the greater presence of women in politics. In 2009, there was actually a higher percentage of unemployed men in comparison to women, mostly due to job losses in certain sectors (manufacturing and construction) highly affected by the economic crisis. The growing number of men taking "maternity" leave also demonstrates that gender stereotypes are gradually changing.

Slovenia needs an active employment policy that is focused on providing work places for less educated young women in the Eastern regions. Since manufacturing companies that have employed low educated women (textiles) are increasingly downsizing, employment possibilities for these women should be encouraged in services. On the other hand, the unemployment spells of women with tertiary education are shorter in comparison to those for men, but still much more frequent. Our database shows that there are 107\% more unemployment spells for women with tertiary education compared to men with the same level of education. This fact indicates unexploited potential and the underuse of female talents, which, if accessed, could contribute to higher competitiveness and the overall stronger economic growth of the country. ㅁ.

\section{References}

Arranz, J. M., and J. M. Romero. 2003. An extra-time duration model with application to unemployment duration under benefits in Spain. CentrA: Fundacion Centro de Estudios Andaluces. Documento de Trabajo. Serie Economia E2003/38.

D'Agostino, A., and F. Mealli. 2000. Modelling short unemployment in Europe. Institute for Social \& Economic Research Working Paper 06.

Daly, K. 2007. Gender inequality, growth, and global ageing. Goldman Sachs Global Economics Paper 154.

Danacica, D.-E. 2009. Employed or unemployed? Influence of gender, age, and educational level. Presented at: Warsaw International Economic Meeting.

http://www.soton.ac.uk/ mkwiek/WIEM2009/Papers/Danacica.pdf (accessed December 8, 2009). 
Domadenik, P., and F. Pastore. 2006. Influence of education and training systems on participation of young people in the labour market of CEE economies. A comparison of Poland and Slovenia. International Journal of Entrepreneurship \& Small Business 3(1): 640-666.

Green, D., and W. C. Riddell. 1995. Qualifying for unemployment insurance: An empirical analysis of Canada. Human Resources Development Canada: Unemployment Insurance Evaluation Series.

Greene, W. H. 2003. Econometric analysis. New York: Prentice - Hall.

Hausmann, R., L. D. Tyson, and S. Zahidi. 2009. The global gender gap report 2009. Geneva: World Economic Forum.

Kajzer, A. 2005. Concept of labour market flexibility and characteristics of labour market in Slovenia. Delovni zvezek 14, UMAR.

Kajzer, A. 2006. A view of labour market conditions for women reflected by labour market indicators. IB revija 3: 72-79.

Kavkler, A., and D. Boršič. 2006. The main characteristics of the unemployed in Slovenia. Naše gospodarstvo 52 (3-4): 3-15.

Kavkler, A., and D. Boršič. 2007. Duration data analysis: Features of unemployment spells in Slovenia. Presented at: Warsaw International Economic Meeting.

http://www.soton.ac.uk/ mkwiek/WIEM2007/Timetable.htm (accessed December 5, 2009).

Klein, J. P., and M. L. Moeschberger. 1998. Survival analysis: Techniques for censored and truncated data. New York: Springer Verlag.

Kupets, O. 2006. Determinants of unemployment duration in Ukraine. Journal of Comparative Economics 34 (2): 228-247.

Lentz, R., and T. Tranaes. 2005. Marriage, wealth, and unemployment duration: A gender asymmetry puzzle. IZA Discussion Paper No. $\quad$ No07. http://papers.ssrn.com/ sol3/papers.cfm?abstract_id=731723 (accessed January 20, 2010).

Löfmark, M. H. 2008. Unemployment duration in Taganrog, Russia. Presented at: Annual EALE Conference, Amsterdam 2008. http://www.eale.nl/Conference2008/Programme/PapersD/add69097_p 1wgRcz5Xj.pdf (accessed January 20, 2010).

Moffitt, R. A. 1999. New developments in econometric methods for labour market analysis. In: O. Ashenfelter, and D. Card (eds). Handbook of Labour Economics. Chapter 24: 1367-1397.

Ollikainen, V. 2006. Gender differences in transitions from unemployment: Micro evidence from Finland. Labour: Review of Labour Economics and Industrial Relations 20 (1): 159-198.

Orazem, P., M. Vodopivec, and R. Wu. 2005. Worker displacement during the transition: Experience from Slovenia. The Economics of Transition 13 (2): 311-40.

Orazem, P. F., J. D. Werbel, and J. C. McElroy. 2003. Market expectations, job search, and gender differences in starting pay. Journal of Labour Research 24(2): 307-321.

R Development Core Team. 2010. R: A Language and Environment for Statistical Computing. Vienna, Austria: R Foundation for Statistical Computing. Available: [http://www.R-project.org]

SORS. 2009a. Labour force survey results: Slovenia 2008. Rapid Reports 35/2009, Statistical Office of the Republic of Slovenia.

SORS. 2009b. Labour force: Slovenia 2008. Rapid Reports 31/2009, Statistical Office of the Republic of Slovenia.

SORS. 2010. Structure of earnings statistics, Slovenia, 2008 provisional data, Statistical Office of the Republic of Slovenia.

Tansel, A., and H. M. Tasci. 2004. Determinants of unemployment duration for men and women in Turkey. IZA Discussion Paper No. 1258. http://papers.ssrn.com/ sol3/papers.cfm?abstract_id=512222 (accessed January 23, 2010).

Therneau, T. M., and P. M. Grambsch. 2000. Modeling survival data: extending the Cox model. New York: Springer Verlag.
Tominc, P., and M. Rebernik. 2010. Inclusion in to the entrepreneurship in Slovenia, Croatia and Hungary: Differences among gender. MBA Razgledi 1-2: 15-25.

United Nations. 2009. Human Development Report 2009. Overcoming barriers: Human mobility and development. United Nations Development Programme.

http://hdr.undp.org/en/media/HDR_2009_EN_Complete.pdf (accessed July 6, 2010).

Vodopivec, M. 1995. Unemployment insurance and duration of unemployment. Evidence from Slovenia's transition. The World Bank. Policy Research Working Paper 1552.

Vodopivec, M. 2004. Labour market developments in the 1990s. In Slovenia: Yugoslavia to the European Union, ed. M. Mrak, M. Rojec and C. Silva-Jáuregui, 292-314. Washington: The World Bank. 